\title{
PERANCANGAN BUKU AJAR DESAIN MOTIF BATIK BERBASIS BUDAYA LOKAL TRENGGALEK UNTUK EKSTRAKURIKULER BATIK TINGKAT SMP
}

\author{
Restu Hendriyani Magh'firoh ${ }^{1}$ \\ Institut Informatika Indonesia, Surabaya ${ }^{l}$ \\ restu@ikado.ac.id
}

\begin{abstract}
Abstrak
Salah satu warisan budaya yang menjadi ciri khas identitas Bangsa Indonesia adalah batik. Pembelajaran dan pelestarian batik di Indonesia sampai sekarang sudah dilaksanakan. Seperti sering diadakannya ekstrakurikuler batik di sekolah. Studi kasus dalam penelitian ini adalah di SMPN 1 Trenggalek. Namun, kegiatan ekstrakurikuler batik kurang diminati oleh siswa karena banyak siswa yang menganggap pembuatan batik itu sulit. Rancangan gambar motif siswa juga kurang bervariatif, cenderung pada gambar tumbuhan, hewan dan geometris. Pengetahuan anak-anak tentang kesenian budaya lokal juga masih terbatas, sehingga perlu dikembangkan melalui menggambar motif batik dengan motif budaya lokal agar wawasan dan kreatifitas anak semakin berkembang. Berdasarkan masalah tersebut, penelitian ini bertujuan merancang buku desain motif batik berbasis budaya lokal Trenggalek dalam bentuk buku ajar untuk Sekolah Menengah Pertama. Pendekatan yang digunakan dalam penelitian ini adalah research and development dan metode yang digunakan Four-D yang dimodifikasi menjadi Three-D. Analisis data dengan skala pengukuran rating scale. Hasil penelitian menunjukkan dengan buku ajar desain motif batik berbasis budaya lokal Trenggalek, siswa berhasil memahami materi tentang batik dan budaya lokal Trenggalek serta mampu lebih kreatif dalam membuat desain motif batik.
\end{abstract}

Kata kunci: Buku Ajar, Motif Batik, Budaya Lokal, Trenggalek, Siswa SMP

\section{Abstract}

One of the cultural heritages that characterizes the Indonesian Nation is batik. Learning and preservation of batik in Indonesia until now has been carried out. As often held batik extracurricular at school. The case study in this study was at SMPN 1 Trenggalek. However, batik extracurricular activities are less attractive to students because many students consider making batik difficult.The design drawings of 
students' motifs are also less varied, designed on plant, animal and geometric drawings. Children's knowledge about local cultural arts is also still limited, so it needs to be developed through batik motifs with local cultural motifs so that children's insight and creativity is growing. Based on these problems, this research discusses the design of batik motifs based on local culture in Trenggalek in the form of textbooks for junior high schools. The research used in this research is research and development and the method used by Four-D is approved to be Three-D. Data analysis with measurement scale assessment scale. The results showed that with textbooks based on local cultural motifs in Trenggalek, students succeeded in discussing material about batik and local culture in Trenggalek and were able to be more creative in making batik motifs.

Key words: Textbook, Batik Motive, Local Culture, Trenggalek, Junior High School Students

\section{PENDAHULUAN}

Batik merupakan salah satu karya ciri identitas Indonesia dari warisan nenek moyang. Batik dinilai sebagai ikon budaya yang memiliki keunikan dan filosofi mendalam, serta mencakup siklus kehidupan manusia, sehingga ditetapkan sebagai warisan budaya dari kemanusiaan. Poerwadarminta (1985: 96) menyatakan bahwa batik sebagai kain dan sebagainya dengan cara tertentu atau mula-mula ditulis dengan atau ditera dengan lilin diwarna soga. Batik adalah kesenian gambar di atas kain untuk pakaian yang menjadi salah satu kebudayaan keluarga raja-raja Indonesia zaman dahulu. Oleh karena itu batik sudah menjadi identitas bangsa melalui ukuran simbol yang unik, warna menawan dan rancangan istimewa. Sehingga pada tanggal 2 Oktober 2009 batik resmi dipatenkan oleh UNESCO sebagai warisan budaya bangsa Indonesia.

Setiap daerah penghasil batik di Indonesia seperti Jogja, Solo, Madura, Cirebon, Banyuwangi dan lain sebagainya memiliki berbagai macam motif batik yang terdapat ciri dan kekhususan yang memberikan kekayaan khasanah bangsa. Salah satunya di wilayah Jawa Timur yaitu Trenggalek. Trenggalek pada masa 70an sampai 80-an cukup dikenal dengan kerajinan batik tulisnya. Banyak orang yang lebih mengenal batiknya daripada kota Trenggalek nya. Hal itu karena sebagian besar masyarakat kabupaten Trenggalek membuat produksi batik dengan ciri khas hasil alam Trenggalek. Batik Sekar Jagad merupakan batik yang paling terkenal karena memberikan ciri khas Trenggalek dengan motif cengkeh. Trenggalek 
merupakan kabupaten yang memiliki potensi ekonomi serta potensi wisata yang cukup baik. Daerah Trenggalek juga memiliki berbagai macam karya seni budaya seperti kerajinan batik, kerajinan bambu, kerajinan gedebog, serta kesenian daerah Tari Turangga Yaksa, Tari Teleng Kencana, Upacara Larung Sembonyo Pantai Prigi, Upacara Nyadran Dam Bagong, serta karya kerajinan dan budaya kesenian lainnya.

Pembelajaran dan pelestarian batik di Trenggalek sampai sekarang sudah dilaksanakan. Seperti sering diselenggarakannya lomba desain dan fashion show batik oleh Bupati Trenggalek yang diikuti oleh para pelajar dan umum. Acara lomba ini merupakan upaya pemerintah kabupaten Trenggalek untuk memasyarakatkan batik khas Trenggalek. Selain itu, diadakannya ekstrakurikuler batik pada sekolah. Ekstrakurikuler menjadi pembelajaran tambahan sangat membantu dalam memperkaya ilmu bagi peserta didik. SMP Negeri 1 Trenggalek adalah salah satu sekolah menengah pertama mengadakan ekstrakurikuler batik dan memiliki perlengkapan membatik yang lengkap dan dijadikan sebagai lokasi penelitian. Pelaksanaan ekstrakurikuler batik dimulai pada tahun ajaran 2011-2012. Kegiatan ekstrakurikuler batik pada awalnya kurang diminati oleh siswa karena banyak siswa yang menganggap pembuatan batik itu sulit dan peminat ekstrakurikuler batik semakin berkurang. Rancangan gambar motif siswa cenderung pada gambar tumbuhan, hewan dan geometris saja. Sebagian besar cenderung menggambar motif bunga. Guru ekstrakurikuler batik juga belum menginspirasi para siswa untuk membuat kreasi dalam mendesain motif batik. Sehingga wawasan kreatifitas siswa dalam mendesain motif batik hanya terbatas. Pengetahuan anak-anak tentang kesenian budaya lokal pun juga masih terbatas. Siswa juga kesulitan untuk mendapatkan buku referensi tentang membuat desain motif batik. Padahal kehadiran buku tentang pembuatan motif ini dirasa sangat penting untuk menunjang pembelajaran membatik.

Buku ajar diperlukan untuk membantu pendidik maupun peserta didik dalam mempelajari maupun memahami bidang studi tertentu dengan tujuan untuk mempermudah dalam proses pembelajaran dan meningkatkan daya tangkap siswa dalam melaksanakan pembelajaran. Para guru membutuhkan buku ajar yang sesuai dengan karakteristik dan kebutuhan siswa dalam belajar, pengadaan buku yang 
relevan dengan mata pelajaran dan sesuai dengan karakteristik dan kebutuhan siswa dan gambar-gambar pembelajaran yang sesuai dengan karakteristik dan kebutuhan siswa (Putu Sukerni, 2014: 386-396). Sehingga dirasa sangat perlunya dilakukan penelitian mengenai bagaimana merancang buku ajar desain motif batik berbasis budaya lokal Trenggalek untuk ekstrakurikuler batik tingkat SMP.

Berdasarkan uraian di atas, maka penelitian ini bertujuan untuk merancang buku ajar desain motif batik berbasis budaya lokal Trenggalek untuk ekstrakurikuler batik tingkat SMP. Buku ajar ini diharapkan dapat memudahkan siswa saat mengikuti proses pembelajaran ekstrakurikuler batik dan lebih kreatif dalam mendesain motif batik dengan mengangkat ragam budaya dan kesenian lokal Trenggalek.

\section{KAJIAN TEORI}

\section{Ekstrakurikuler}

Sumarwan (2003: 11) mengemukakan bahwa ekstrakurikuler adalah wahana pengembangan pribadi peserta didik melalui berbagai kegiatan, baik yang terkait langsung maupun tidak langsung dengan materi kurikulum, dan sebagai bagian tak terpisahkan dari tujuan kelembagaan sekolah. Pengembangan diri bertujuan memberikan kesempatan kepada peserta didik untuk mengembangkan dan mengekspresikan diri sesuai dengan kebutuhan, bakat dan minat setiap peserta didik sesuai dengan sekolah. Ekstrakurikuler bagi pelajar diharapkan dapat turut memberikan kontribusi dalam membentuk pelajar sekolah dasar dan sekolah menengah menjadi generasi yang kreatif dan memiliki logika serta nalar yang baik untuk menyerap berbagai hal yang positif yang ada di sekitarnya.

\section{Buku Ajar}

Di tengah pesatnya penggunaan IT di berbagai bidang, buku masih menjadi sumber bacaan utama baik dalam keseharian maupun sebagai sumber belajar dalam proses pembelajaran. Buku ajar merupakan komponen yang penting dalam sebuah proses pembelajaran. Berdasarkan analisis, kebutuhan para guru membutuhkan buku ajar yang sesuai dengan karakteristik dan kebutuhan siswa dalam belajar. 
pengadaan buku yang relevan dengan mata pelajaran dan sesuai dengan karakteristik dan kebutuhan siswa dan gambar-gambar pembelajaran yang sesuai dengan karakteristik dan kebutuhan siswa (Putu Sukerni, 2014: 386-396).

Buku ajar yang baik harus memenuhi kriteria penilaian yang meliputi aspek kesesuaian isi dengan kurikulum, penyajian materi, keterbacaan, dan kemudahan dipahami oleh pembaca atau siswa. Oleh karena itu perlu dilakukan kajian mengenai aspek-aspek tersebut untuk memastikan bahwa buku ajar tersebut layak pakai (Suharyadi, 2013: 60-68).

\section{Batik}

Batik dinilai sebagai ikon budaya yang memiliki keunikan dan filosofi mendalam, serta mencakup siklus kehidupan manusia. Batik adalah lukisan atau gambar pada mori yang harus dibuat dengan menggunakan canting. Orang melukis atau menggambar pada mori memakai canting disebut membatik (bahasa Jawa: mbatik). Membatik menghasilkan batik atau batikan berupa bermacam-macam motif dan memiliki sifat-sifat khusus yang dimiliki oleh batik itu sendiri (Hamzuri, 1981: VI).

Desain-desain batik sudah mengikuti perkembangan zaman sesuai dengan inovasi yang diciptakan oleh masyarakat zaman sekarang. Batik khas Trenggalek terkenal dengan motif Sekar Jagad yang menunjukkan karakteristik daerah dengan penambahan motif cengkeh serta manggis. Motif Sekar Jagad mengandung makna kecantikan dan keindahan. Sekar yang berarti "bunga" dan Jagad yang berarti "alam semesta". Sehingga motif ini juga melambangkan keragaman diseluruh dunia. Sekar Jagad yang ada di Trenggalek mempunyai ciri khusus yaitu adanya penambahan motif cengkeh yang menunjukkan karakteristik daerah Trenggalek (Wulandari, 2010: 16).

\section{Budaya Lokal Trenggalek}

Budaya lokal merupakan adat-istiadat, kebudayaan yang sudah berkembang atau sesuatu yang sudah menjadi kebiasaan yang sukar diubah dan terdapat disuatu daerah tertentu (Koetnjaraningrat 1997: 20). Dengan demikian budaya lokal dapat dimaknai sebagai identitas, kearifan, kelebihan, keunggulan 
dari suatu daerah sehingga daerah itu mempunyai ciri khas yang berbeda dengan daerah lainnya. Kabupaten Trenggalek memiliki banyak ragam budaya seperti budaya seperti upacara ritual adat dan kesenian daerah. Beberapa adat dan kesenian budaya lokal yang ada di Trenggalek yaitu: Jaranan Turonggo Yakso, Larung Sembonyo, Nyadran Dam Bagong, Tari Teleng Kencono.

\section{Desain Motif Batik}

Menciptakan motif batik bukan urusan mudah. Dibutuhkan ketelitian dan kreativitas tinggi untuk menciptakan kreasi desain yang memiliki nilai artistik tinggi. Umumnya penampilan motif sangat dipengaruhi dan erat hubungannya dengan faktor-faktor seperti letak geografis pembuat batik, sifat dan tata kehidupan, kepercayaan dan adat, keadaan alam, dan nilai budaya daerah, sejarah, simbol-simbol baru yang diinovasi dan dimodifikasi, adanya kontak atau hubungan antar daerah pembatikan (Nanang, 2003: 1-22). Para pengrajin batik perlu untuk terus mengembangkan jenis-jenis motif batik yang baru sebagai upaya keikutsertaan mereka dalam pasar komoditas. Salah satu upaya pengembangan dapat dilakukan melalui eksplorasi bentuk khas dari masing-masing daerah penghasil batik. Desain-desain batik diambil dari motif budaya tradisi dan kesenian lokal yang dipilih ataupun di kombinasikan, agar tercipta motif batik yang mempunyai filosofi sesuai dengan ciri khas karakter daerahnya. Desain motif dapat dimodifikasi dengan teknik stilasi, distorsi, tranformasi, dan deformasi sehingga bisa menghasilkan desain-desain yang lebih unik.

\section{METODE PENELITIAN}

Pendekatan yang digunakan dalam penelitian ini adalah research and development dan metode yang digunakan Four-D model yang disarankan oleh Thiagarajan, (1974: 5-8) yang dimodifikasi menjadi Three-D. Analisis data yang digunakan adalah kuantitatif dan kualitatif. Subjek penelitian 20 siswa peserta ekstrakurikuler batik yang teridiri dari kelas VII dan VIII SMPN 1 Trenggalek. Instrumen pengumpulan data menggunakan angket. Teknik analisis data yang digunakan adalah analisis deskriptif dan statistik deskriptif. Data observasi dianalisis menggunakan analisis deskriptif, sedangkan data dari angket dianalisis menggunakan statistik deskriptif. 


\section{HASIL DAN PEMBAHASAN}

Berdasarkan hasil penelitian perancangan buku ajar desain motif batik berbasis budaya lokal Trenggalek ketika diterapkan di ekstrakurikuler adalah berhasil atau siswa menjadi lebih memahami materi tentang batik dan mengetahui macam budaya lokal Trenggalek serta lebih kreatif dalam mendesain motif batik.

\section{Proses Perancangan Buku Ajar}

\section{Tahap Pendefinisian (Define)}

Tahap ini menentukan dan mendefinisikan syarat-syarat perancangan buku ajar. Terdapat lima langkah pokok dalam tahap ini, yakni analisis ujung depan, analisis siswa, analisis tugas, analisis konsep dan perumusan tujuan.

Analisis ujung depan bertujuan memecahkan suatu masalah yang mendasar yang dihadapi. Berdasarkan latar belakang maka masalah yang teridentifikasi ialah pentingnya menumbuhkan minat siswa pada pembelajaran batik dengan materi objek desain motif. Penggambaran desain motif kurang menarik dan kurang kreatif.

Analisis siswa bertujuan untuk menelaah karakteristik siswa sehingga semua rancangan buku ajar berbasis budaya lokal yang disusun dapat menunjang dan mengakomodasi kebutuhan dasar siswa sebagai subjek belajar. Hasil dari analisis siswa dijadikan pertimbangan untuk mengembangkan sejauh mana buku ajar yang akan dibuat dan mampu diterima oleh siswa dengan harapan akan semakain maju.

Analisis tugas dilakukan untuk isi buku ajar dalam bentuk garis besar isi materi pokok yang mencangkup pemahaman tugas pada suatu pembelajaran. Analisis tugas disesuaikan dengan tujuan dan target pembelajaran.

Analisis konsep bertujuan untuk memilih, menetapkan dan menyusun secara sistematis buku ajar yang akan dirancang. Analisis konsep dilakukan dengan sumber dasar kajian pustaka dan lapangan. Konsep buku ajar desain motif batik berbasis budaya lokal ini dibagi berdasarkan konsep wujud (form) dan isi (value). Form dikembangkan berdasarkan kesukaan anak terhadap bahan bacaan yang di dalamnya memuat gambar, untuk itu sangat penting bagi peneliti mengetahui bagaimana karakter si pengguna agar produk yang dirancang menjadi tepat guna. 
Sedangkan konsep isi (value) berisi ide-ide atau nilai-nilai apa saja yang menjadi sebagai pemecahan masalah.

Analisis tujuan pembelajaran dilakukan untuk memadukan mulai dari analisis ujung depan, analisis siswa, analisis tugas sampai pada analisis konsep. Tujuan pembelajaran ini dijadikan dasar pijakan untuk penyusunan buku ajar desain motif batik berbasis budaya lokal Trenggalek yang benar-benar sistematis.

\section{Tahap Perancangan (Design)}

(a) Pemilihan Media (media selection)

Dari hasil analisis serta karakteristik siswa sekolah menengah pertama menyukai buku dengan gambar daripada buku teks secara keseluruhan. Selain itu, peran buku masih dianggap sebagai sumber belajar utama di setiap tingkat pendidikan.

Dari data analisis di atas, maka karakteristik buku yang tepat adalah:

(1) Buku dengan visualisasi yang menarik.

(2) Media dalam bentuk buku yang banyak memuat gambar.

(3) Buku praktis sehingga bisa dibuka dan dipelajari dimanapun berada serta kapanpun.

(4) Bisa digunakan sebagai koleksi oleh pengguna.

(b) Pemilihan Format (format selection)

Format yang dipilih dalam pengembangan buku ini sebagai berikut:

(1) Buku dengan ukuran A4, sesuai dengan ukuran yang lebih besar pada umumnya.

(2) Format isi buku yaitu tulisan dan gambar berupa ilustrasi.

(3) Untuk tulisan dominan menggunakan hitam dan pada gambar dibuat sebagian besar full colour.

(4) Seluruh kertas dalam buku menggunakan art paper 160 gram agar lebih menarik untuk dibaca dan awet.

(c) Rancangan Awal (Initial Design)

Tahap dari rancangan awal media buku ajar desain motif batik berbasis budaya lokal Trenggalek adalah sebagai berikut: 
(1) Mengumpulkan hasil penelitian

Mengumpulkan hasil penelitian sebelumnya sangat penting untuk mengetahui sejauh mana perancangan ini dikembangkan serta mengetahui kedudukannya dalam penelitian.

(2) Desain Media

(a) Konsep Lay Out

Konsep disusun dalam klasifikasi penulisan untuk memudahkan proses perancangan agar produk dirancang secara sistematis. Konsep meliputi aspek grafik dan isi.

Acuan dalam perancangan pada tahap ini mendasar pada tahap sebelumnya yaitu tahap pendefinisian. Buku ajar dengan full colour dipilih sebagai buku acuan dalam belajar mendesain motif batik berbasis budaya lokal. Dalam buku terdapat isi berupa materi pengetahuan yang disertai lebih banyak gambar dan full colour. Konsep penyusunan materi dalam buku ajar desain motif batik berbasis budaya lokal ini mengambil materi seputar batik (pengertian batik, media batik, batik Trenggalek, motif batik), ragam budaya lokal Trenggalek (jaranan turonggo yakso, tari teleng kencono, larung sembonyo, nyadran dam bagong dan hasil alam dari Trenggalek), teori pengembangan ide, pola batik, dan pemilihan warna.

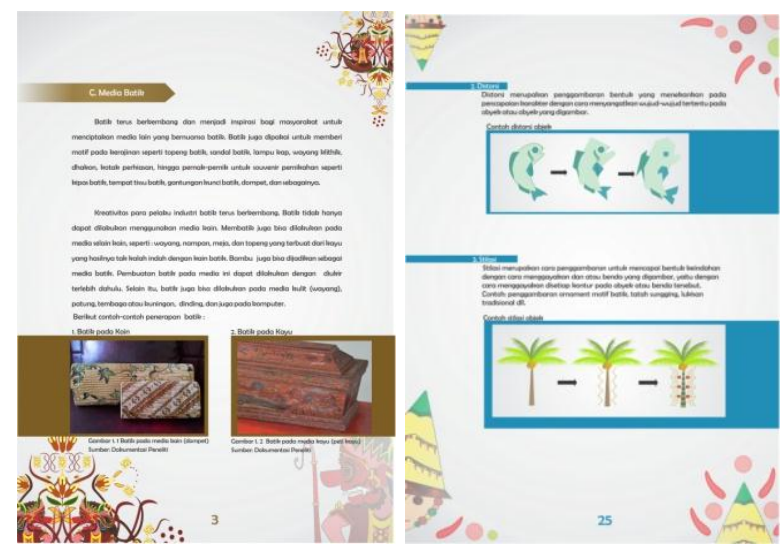




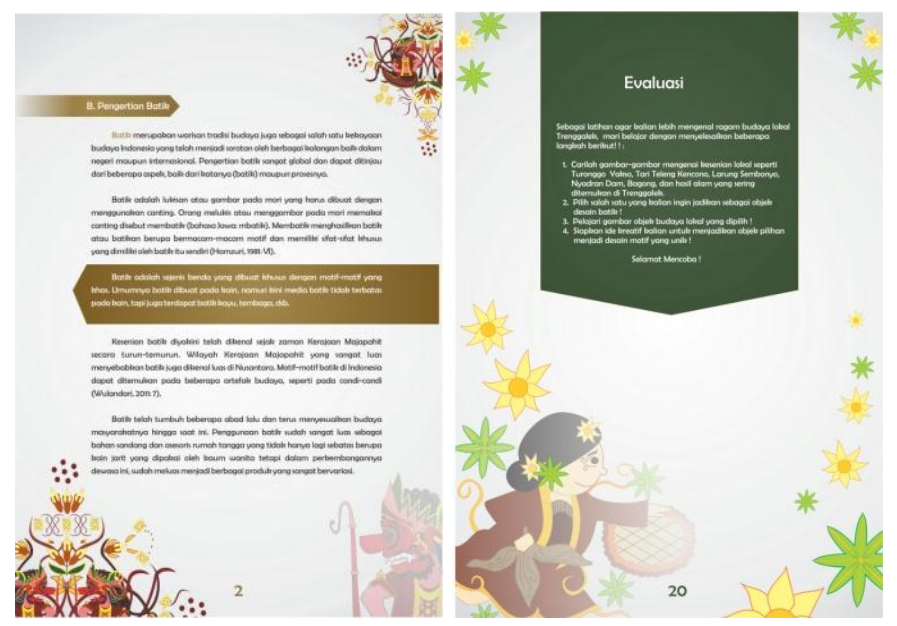

Gambar 1. Lay Out Penyajian

Sumber: Dokumentasi Penulis
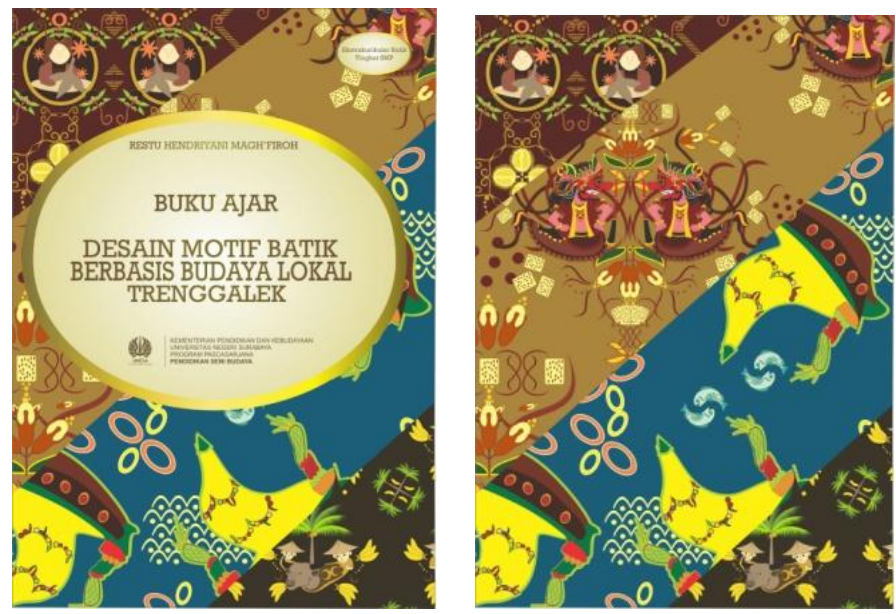

Gambar 2. Desain Cover Belakang

Sumber: Dokumentasi Penulis

Pemaknaan gambar objek desain motif didasarkan pada karakter wujud objek dan penggunaan warna. Pengembangan ide desain tidak harus menyerupai wujud asli, namun tetap menunjukkan karakternya. Pemberian warna pada objek desain disesuaikan dengan karakternya. 


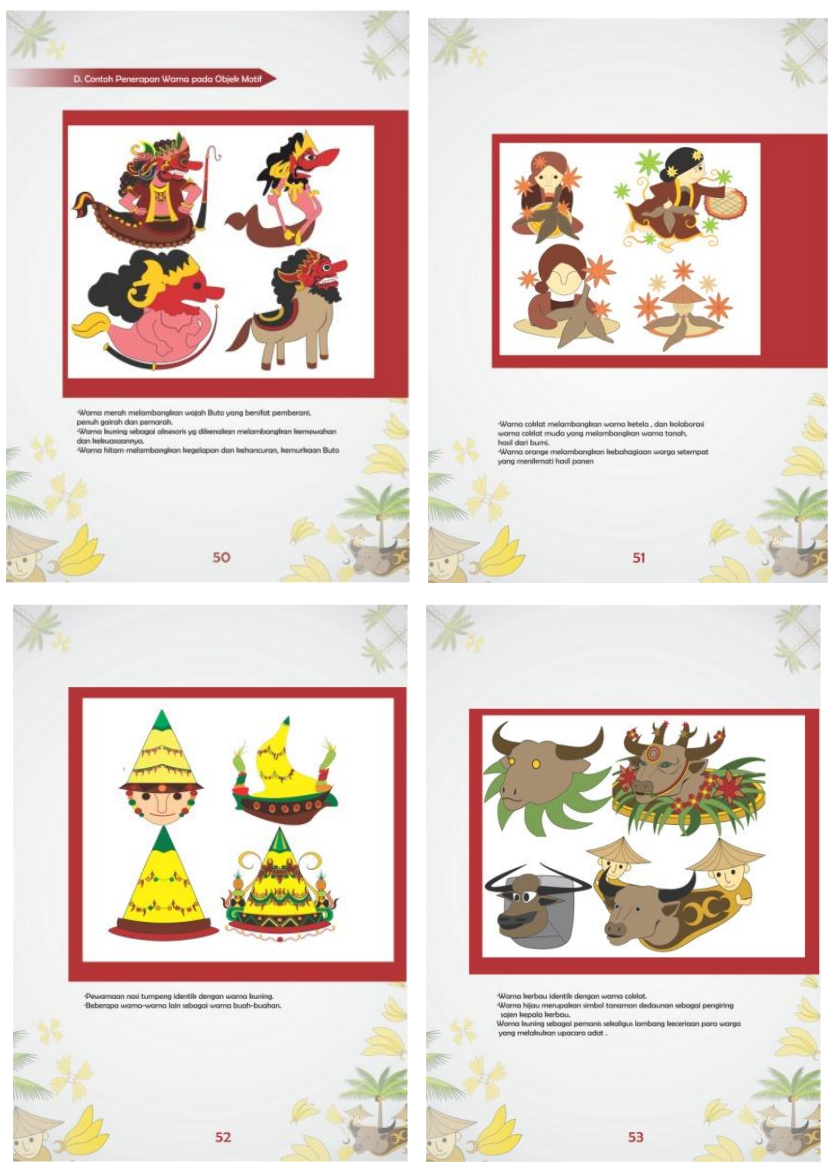

Gambar 3. Pengembangan desain motif sesuai karakter Sumber: Dokumentasi Penulis

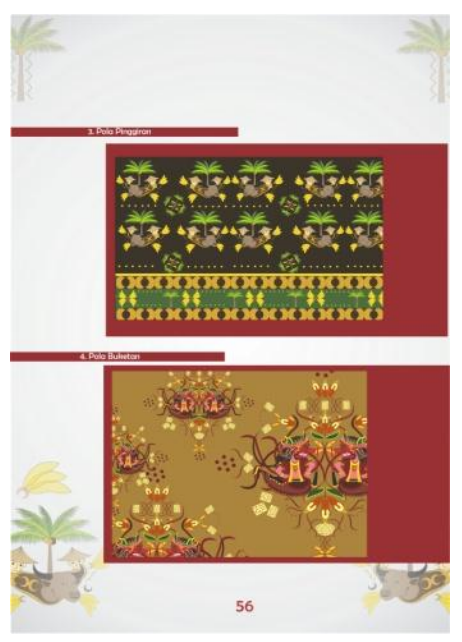

Gambar 4. Format contoh pola motif Sumber: Dokumentasi Penulis 


\section{Tahap Pengembangan (Develop)}

Tahap pengembangan adalah tahap untuk menghasilkan produk yang dilakukan melalui dua langkah yaitu:

(a) Penilaian ahli (expert appraisal)

Tujuan tahap ini adalah utnuk menghasilkan bentuk akhir buku ajar. Validasi buku ajar dilakukan oleh praktisi pendidikan ekstrakurikuler seni yang dibidang pendidikan seni yang lebih spesifiknya adalah budaya dan batik. Rekomendasi dari validator akan menjadi bahan rujukan untuk sebuah perbaikan dan akan menghasilkan draf ke II.

(b) Uji coba Pengembangan (developmental testing)

Uji coba lapangan dilakukan untuk memperoleh masukan langsung berupa respon, reaksi, komentar siswa dan para pengamat terhadap buku ajar yang telah dikembangkan.

\section{Kualitas Perancangan Buku Ajar}

Kualitas buku ajar yang dirancang ditentukan dari dua kriteria yaitu kualitas buku ajar berdasarkan produknya (isi, penyajian bahasa, dan kegrafikaan), dan kualitas buku ajar berdasarkan penggunanya (respon guru, respon siswa dan aktifitas siswa).

Kualitas berdasarkan produknya dapat diketahui dari hasil validasi oleh para pakar/ahli dan praktisi. Hasil validasi materi, penyajian, kebahasaan dan kegrafikaan berdasarkan kelayakan BSNP 2007, sudah sesuai dan layak untuk digunakan. Kualitas berdasarkan pengguna dilihat dari hasil pada uji coba I dan II penilaian respon guru terhadap buku ajar desain motif batik berbasis budaya lokal Trenggalek sangat baik, menunjukkan bahwa buku ajar sudah dirasa sangat relevan. Aktivitas siswa menunjukkan bahwa siswa sudah dirasa sangat aktif mendesain motif batik berbasis budaya lokal. Respon siswa dirasa memberikan tanggapan yang baik terhadap pembelajaran dengan menggunakan buku ajar desain motif batik berbasis budaya lokal Trenggalek. Hal demikianlah membuktikan buku ajar desain motif batik berbasis budaya lokal Trenggalek layak digunakan dalam pembelajaran khususnya pembelajaran ekstrakurikuler batik. 


\section{SIMPULAN DAN SARAN}

\section{Simpulan}

Dalam penelitian ini dapat disimpulkan bahwa perancangan buku ajar desain motif batik berbasis budaya lokal Trenggalek untuk ekstrakurikuler tingkat SMP ini memberikan kontribusi yang cukup signifikan dalam proses pembelajaran batik. Kualitas buku ajar desain motif batik berbasis budaya lokal Trenggalek untuk siswa SMP yang dirancang ditentukan oleh kualitas buku ajar berdasarkan produknya dan berdasarkan penggunanya. Dari hasil uji coba juga menunjukkan bahwa siswa dirasa sangat aktif dan kreatif dalam mendesain motif batik. Terdapat perbedaan yang sangat signifikan antara sebelum dan sesudah menggunakan buku ajar desain motif batik berbasis budaya lokal Trenggalek. Hasil sebelumnya para siswa kebanyakan mendesain motif batik dengan motif bunga, sulur-suluran, dan geometris saja. Namun setelah menggunakan buku ajar, hasil desain motif batik siswa lebih variatif dan mampu menunjukkan ciri khas budaya lokal Trenggalek dengan berbagai motif kesenian daerah serta hasil alamnya.

Berdasarkan hasil validasi dan uji coba, buku ajar desain motif batik berbasis budaya lokal Trenggalek tergolong layak digunakan sebagai pelestarian batik dan pengenalan budaya lokal Trenggalek dan sebagai penunjang pembelajaran ekstrakurikuler batik di sekolah. Sehingga siswa mampu lebih kreatif dalam mendesain motif batik dengan keanekaragaman budaya daerah.

\section{Saran}

Dengan pemanfaatan buku ajar desain motif batik berbasis budaya lokal Trenggalek ini diharapkan dapat memudahkan siswa untuk mempelajari bagaimana membuat desain motif batik berbasis budaya lokal khususnya Trenggalek, dapat digunakan sebagai acuan dalam pembelajaran ekstrakurikuler batik baik untuk guru Pembina, siswa serta sekolah.

\section{DAFTAR PUSTAKA}

Hamzuri. 1981. Batik Klasik. Jakarta: Djambatan

Koentjaraningrat. 1997. Kebudayaan Mentalitas. Jakarta : Gramedia. 
Nanang, Herman, Saftiyaningsih. 2003. Batik Garut Kajian Bentuk dan Warna.

Jurnal Wacana Seni Rupa Vol. 3 No.6 Agustus 2003, 1-22.

Poerwadarminta. 1985. Kamus Umum Bahasa Indonesia. Jakarta: Balai Pustaka.

Suharyadi, Anna, Hernani. 2013. Pengembangan Buku Ajar Berbasis Kontekstual Pada Pokok Bahasan Asam dan Basa. Jurnal Riset dan Praktek Pendidikan Kimia. ISSN: 2301-721X. Vol 1 No. 1 Mei 2013, 60-68. Jurusan Pendidikan Kimia FPMIPA: UPI.

Sukerni, Putu. 2014. Pengembangan Buku Ajar Pendidikan Ipa Kelas Iv Semester

I Sd No. 4 Kaliuntu Dengan Model Dick And Carey. Issn: 2303-288x Vol.

3, No. 1, April 2014, 386-396. Singaraja, Indonesia.

Sumarwan. 2003. Pengembangan Program Pendidikan dan Pelatihan Tata Busana

Sebagai Implementasi Pendidikan Kecakapan Hidup (Life Skills

Education) Melalui Kegiatan Ekstrakurikuler di SMU Negeri 2

Pamekasan. Tesis tidak diterbitkan. Surabaya: UNESA.

Thiagarajan, S.S \& Semmel, M.I. 1974. Instructional Development for Training

YTeacher of Expectional Children. Minneapolis, Minnesota: Leadership

Training Institude/ Special Education, University of Minnesota.

Wulandari, Ari. 2011. Batik Nusantara. Yogyakarta: ANDI. 